\title{
Classification of smooth muscle autoantibodies detected by immunofluorescence
}

\author{
GIAN-FRANCO BOTTAZZO, ALEJO FLORIN-CHRISTENSEN, ANDREW \\ FAIRFAX, GRANVILLE SWANA, DEBORAH DONIACH, AND \\ UTE GROESCHEL-STEWART
}

\begin{abstract}
From the Department of Immunology, The Middlesex Hospital Medical School, London WI and Universitäts Frauenklinik, Würzburg, West Germany
\end{abstract}

SYNOPSIS Three hundred and twelve sera containing antibodies to smooth muscle (SMA) were analysed for the immunofluorescence patterns they produced in various tissues. A classification is described based on the three main appearances in rat kidney. Some sera, mainly of low titre, reacted only with vessel walls (SMA-V), some stained vessels and renal glomeruli (SMA-G) and high titre sera, mainly from patients with chronic active hepatitis stained vessels, glomeruli, and intracellular fibrils in renal tubules (SMA-T). Peripheral staining in hepatocytes or thyroid cells was not a regular feature. $41 / 43$ polyclonal SMA-T and -G sera were absorbed out completely by actin, and this also removed the pericellular staining in liver and thyroid when present. High titre SMA-V antibodies could not be absorbed by actin, and the antigen remains to be identified.

Smooth muscle antibodies of low titre are found by immunofluorescence (IFL) in $12 \%$ of normal subjects (Holborow et al, 1973; Sutton et al, 1974) and as a temporary phenomenon in up to $80 \%$ of patients with virus infections, especially infectious hepatitis (Farrow et al, 1970; Ajdukiewicz et al, 1972; Walker et al, 1970), infectious mononucleosis (Holborow et al, 1973; Sutton et al, 1974) and warts (McMillan and Haire, 1975). They are also seen in malignancies not necessarily involving the liver (Whitehouse and Holborow, 1971; Wasserman et al, 1975). These antibodies are unrelated to age and sex and their frequency is not increased in families predisposed to autoimmunity (Galbraith $e t$ al, 1974). It is thought that they are produced in response to tissue injury following the release of proteins from the cells (Holborow, 1972; Becker and Nachman, 1973; Behnke, 1974).

SMA were first described in patients with chronic active hepatitis (Johnson et al, 1965; Doniach et al, 1966; Whittingham et al, 1966a), and it is true that the highest titres are seen in this disease where they may persist for years. In addition to their reaction with smooth muscle fibres in all tissues from various species, it was soon noted that some sera also stained renal glomeruli (Whittingham et al, 1966b). Fluorescence of intracellular fibrils in the peripheral cyto-

Received for publication 5 October 1975 plasm of liver cells includes the 'polygonal' and socalled 'bile-canalicular' patterns (Johnson et al, 1966; Farrow et al, 1971). Similar staining occurs in thyroid (Sutton et al, 1974; Biberfeld et al, 1974; Lidman et al, 1974). However, peripheral IFL is also seen without associated smooth muscle fibre staining (Fairfax et al, 1976).

The multiple staining patterns observed with sera from patients with chronic liver diseases and, more significantly, with monoclonal immunoglobulins having SMA reactivity (Wager et al, 1971; Roux et al, 1974) imply that several antigens are involved in these reactions.

\section{Material and Methods}

PATIENTS' SERA

One hundred and forty sera with SMA titres of 80640 , derived mainly from liver cases and patients with collagen disorders, were selected from a large number tested. To assess the general frequency of SMA, 1060 sera were scanned and 172 reactions with titres of $10-40$ were classified into the different SMA patterns. Sera were tested fresh or after storage at $-20^{\circ} \mathrm{C}$ for up to five years.

IMMUNOFLUORESCENCE

In order to see small intracellular fibrils it is essential to have epiillumination. The present studies were 
done with a Leitz Ortholux UV microscope fitted with a Ploem illuminator and HB200 mercury vapour lamp. The sandwich technique was employed throughout with FITC-labelled anti-Fab conjugates and serum dilutions starting at $1: 10$, titred to end point. Unfixed cryostat sections of a composite block consisting of thyrotoxic thyroid, human stomach, and rat liver and kidney were employed for screening and titrations. Other organs included human pancreas, human, calf, and mouse thymus, rat stomach, and striated and cardiac muscle (Fairfax and Doniach, 1976).

EXTRACTION OF CONTRACTILE PROTEINS Whole smooth muscle homogenates from human uterus (Anderson, 1974) and pig stomach (Fagraeus et $a l, 1973)$ have been shown to absorb SMA sera. Therefore we attempted to identify the antigen by using subfractions. Actin was prepared by the method described by Adelstein et al (1963), actomyosin according to Becker (1972), and myosin according to Huriaux et al (1967) from fresh human uterus and from ox stomach.

\section{ABSORPTION OF SMA WITH MUSCLE PROTEINS}

For this, serum dilutions in Coons' buffer were made to give definite SMA IFL, 1-2 tubes below the end point titre. $0.2 \mathrm{ml}$ of the chosen dilution was incubated with an equal volume of decreasing concentrations of each protein fraction starting with $10 \mathrm{mg} / \mathrm{ml}$. The mixture was incubated for 60 minutes at $37^{\circ} \mathrm{C}$ followed by overnight shaking at $4^{\circ} \mathrm{C}$. After centrifugation at $20000 \mathrm{~g}$ for $30 \mathrm{~min}$, the supernatant was tested by IFL. Controls included SMA incubated with saline, and sera with thyroid, ANA, and mitochondrial antibodies absorbed with the same smooth muscle proteins.

\section{Results}

IMMUNOFLUORESCENCE PATTERNS

The sera studied could be classified into three distinct IFL patterns based on the appearances in rat kidney (table I). By definition, all sera stained smooth muscle fibres. It was found that these fibres did not differ with regard to species, organ substrates or their location in vessel walls, muscularis mucosae, hepatic portal tracts or interglandular fibres. Rat kidney provided vessels which were slightly more sensitive than stomach, and additional landmarks in glomeruli and peritubular fibrils.

\section{$S M A-V$ (vessels)}

These sera stained the vessel walls exclusively (fig 1). Fifty per cent of all positive sera appeared to give

\begin{tabular}{llll}
\hline Tissues (all species) & \multicolumn{2}{l}{ Smooth Muscle Variant } \\
\cline { 2 - 4 } & $S M A-V$ & $S M A-G$ & $S M A-T$ \\
\hline $\begin{array}{c}\text { Smooth muscle fibres (vessel walls, } \\
\text { muscularis mucosae layers, } \\
\text { interglandular fibres, etc) }\end{array}$ & & & \\
$\begin{array}{l}\text { Renal glomeruli (best in mouse } \\
\text { and rat) }\end{array}$ & & &
\end{tabular}

Table I Classification of smooth muscle patterns by immunofluorescence

$\mathrm{V}=$ vessels $; \mathrm{G}=$ glomeruli $; \mathrm{T}=$ tubules.

this pattern. Most were of low titre $(<40)$ and these cannot be classified accurately by morphology.

\section{SMA-G (glomeruli)}

These sera stained only vessel walls and glomeruli(fig 2). The glomerular IFL was of mesangial distri3 bution with many of the sera and was more cons tinuous compared with the small interrupted lineso seen with sera of the third pattern. SMA-G was obtained with $22 \%$ of the sera.

\section{SMA-T (tubular)}

These sera stained the entire glomerulus. Wit strong sera this could be seen to consist of a mass o⿸尸 short slender fibrils in and around the GBM and in the mesangium. Interrupted fine IFL lines could be seen around the tubular basement membrane and or the inner edge of the cells (fig 3). This distribution of staining was obtained with $28 \%$ of SMA sera. Many high titre sera with this appearance on kidney gave more complex peripheral IFL in other organs, ine cluding exocrine pancreas, thyrotoxic thyroid, and.

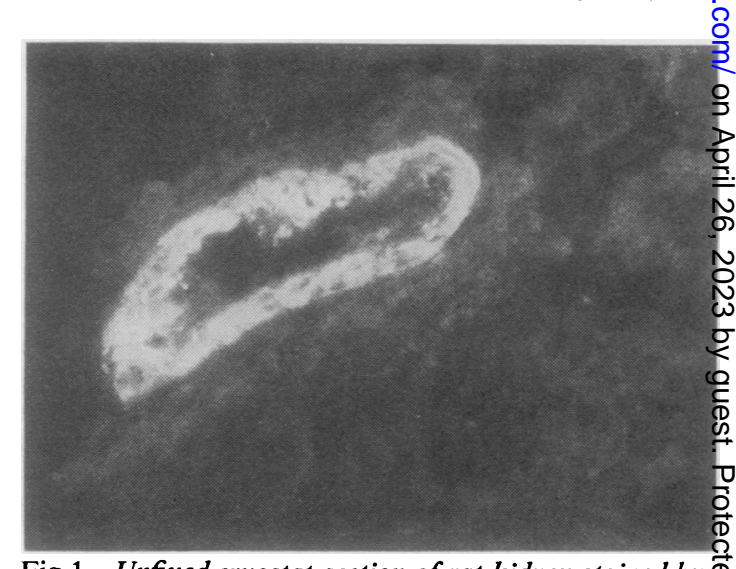

Fig 1 Unfixed cryostat section of rat kidney stained by IFL with serum containing SMA-V antibodies, showing positive vessel wall and negative glomerulus (bottom rights hand corner) and tubules. 
liver. Staining around hepatocytes could be continuous (polygonal) or double and interrupted (bile canalicular). With occasional sera there was an intracellular network of fine fibrils in gastric parietal cells and hepatocytes.

The staining of the actual smooth muscle fibres did not differ consistently in SMA-V, - G or - T sera although individual appearances were not always identical. The three patterns could be distinguished clearly from each other only with fairly high titre sera, and on increasing dilutions the vascular SMA could be seen beyond the point where small fibrils in glomeruli and epithelial structures became invisible. The same three patterns were obtained with human, rat, and mouse kidney.

REACTIONS WITH SKELETAL MUSCle

In view of the localization of actin in the I-bands of skeletal muscle, SMA-T and -G sera should show striational IFL if this is the main antigen. On cryostat sections this could be seen only with hightitre sera, and the IFL was always weaker than on smooth muscle fibres.

THYMUS, LYMPH-NODE, AND SPLEEN IFL

Eighty-two sera were tested on mouse, calf or human thymus. No species differences could be detected so most of the detailed work was done on mouse thymus. Twenty-nine sera stained both medulla and cortex (fig 4), 18 reacted with medulla, and 35 were negative. The staining consisted of a cytoplasmic rim in the periphery of thymocytes in acetone-fixed sections. Viable thymocytes showed no staining with any SMA sera. In addition, 17 sera gave' a streaky IFL in the cortical area (fig 5). Correlation of SMA patterns with thymic reactivity is shown in table II. Twenty-six of the 29 sera giving positive IFL in both medulla and cortex belonged to the SMA-T group, while none of the SMA-V showed any reactivity with the thymus. Of 17 sera showing 'streaks' in the cortex, 13 were SMA-T and four were SMA-G; none of the SMA-V sera showed this reactivity.

Since it was suggested that SMA sera could stain T-cells selectively (Fagraeus et al, 1973) a comparison was made with an anti-mouse brain associated theta (BA- $\theta$ ) (Gyöngyössy and Playfair, 1973) using the double IFL technique with rhodamine and FITC. SMA sera reacting only with thymic medulla, or those which stained both medulla and cortex, gave the same pattern as anti-theta on lymph node and spleen, ie, they stained only the T-lymphocytes. In the thymus, anti-theta was always brighter on cortical lymphocytes. 'Streaks' were never seen with anti-theta (table III).

\section{CLINICAL ASSOCIATIONS OF SMA} FLUORESCENCE

Of 312 sera in which the SMA pattern was determined, 139 came from patients with liver disorders and 173 mainly from patients with viral infections, autoimmune disorders, and a variety of malignancies (table IV). The overall distribution of patterns showed that half the sera were SMA-V, $28 \%$ were SMA-T, and $22 \%$ SMA-G. High titres (80-640) of

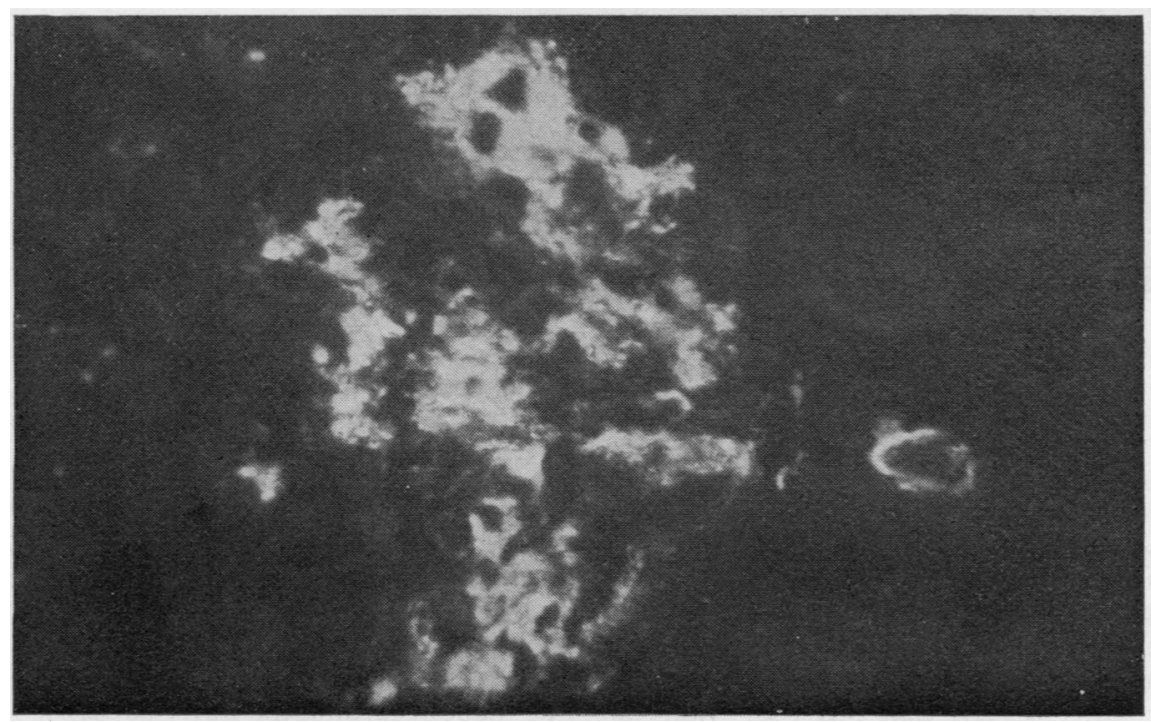

Fig 2 Rat kidney stained by IFL with serum containing SMA-G antibodies, showing positive vessel wall and segmental IFL of glomerulus, with negative tubules. 


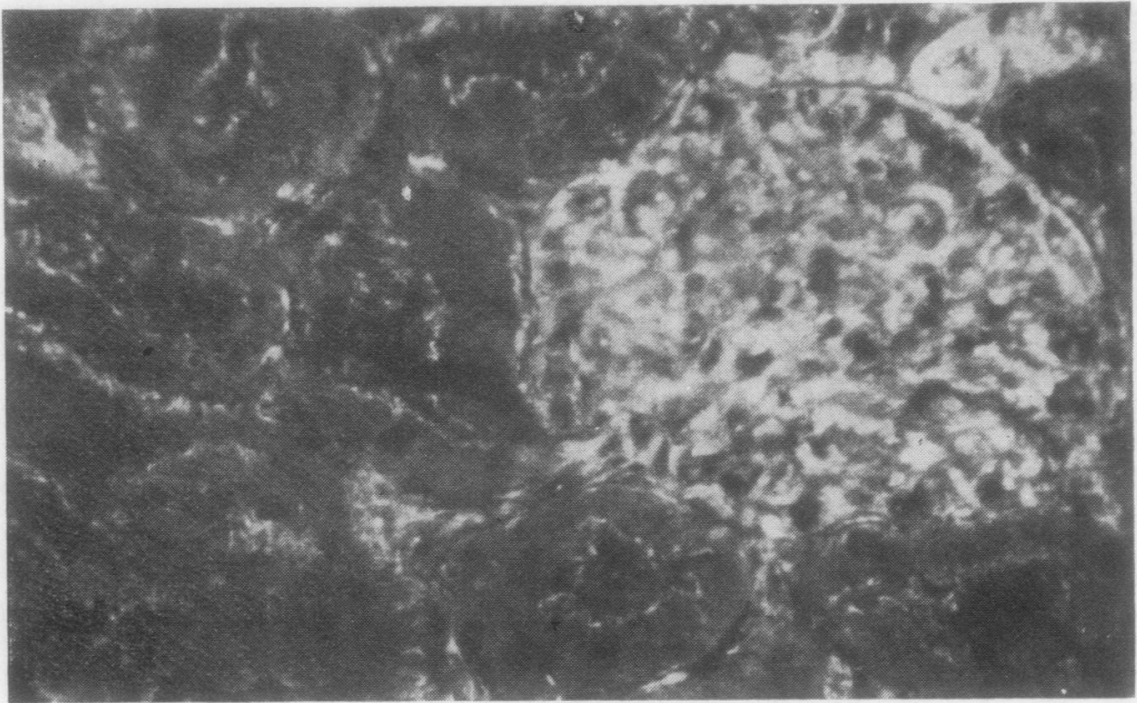

Fig 3 Rat kidney stained with serum containing SMA-T antibodies, showing diffuse glomerular IFL and multiple small fibrils in renal tubules.

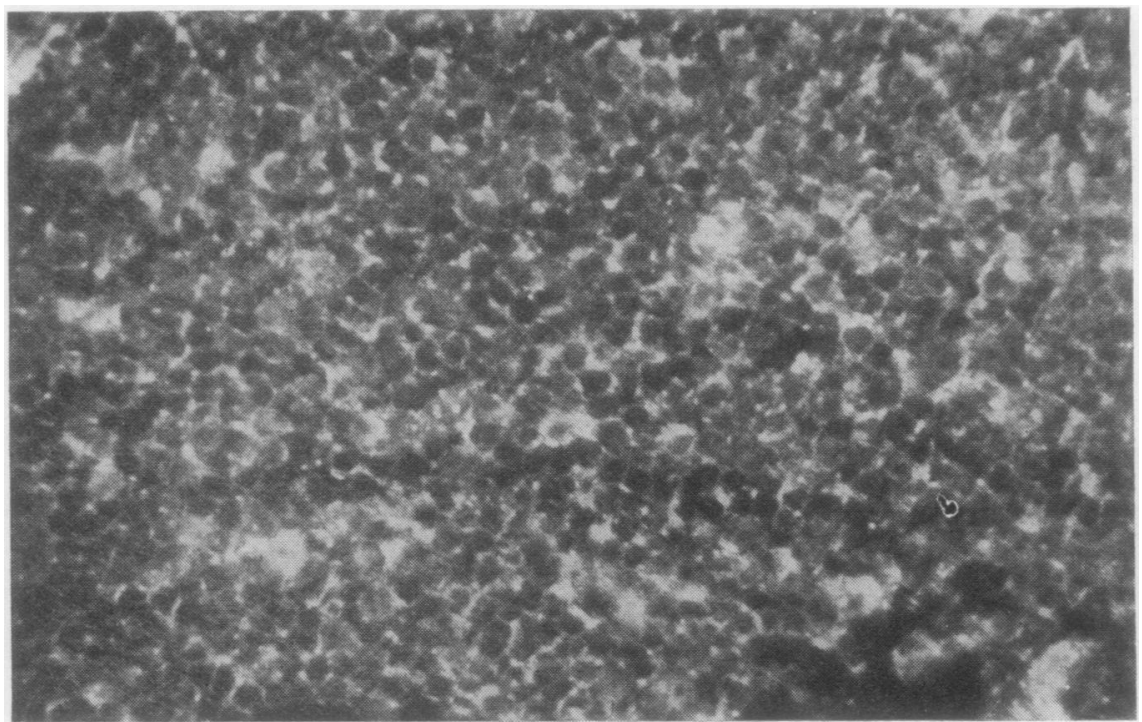

Fig 4 Calf thymus showing IFL of cortex with SMA-T serum.

SMA-T and - $G$ were more frequent in chronic liver diseases while SMA-V showed a higher prevalence in the group of miscellaneous conditions, and at low titres also in liver cases.

Assessment of the distribution of SMA variants in liver disorders was confined to high titres since these are more significant in relation to 'autoimmune' liver diseases (table V). Sera from patients with chronic active hepatitis (CAH) had SMA-T and $-G$ about equally and SMA-V less often $\left(3 / 42 \frac{9}{9}\right.$ 'Autoimmune' CAH cases were subdivided int those who also had high ANA titres (lupoid variant) and a much less frequent disease where persister SMA is the only marker (Doniach and Bottazz $\overrightarrow{\dot{B}_{3}}$ 1976). In viral hepatitis SMA titres rarely go above 80 and SMA-T and $-V$ tended to be more frequen? Cirrhosis represents a mixed group, and no correl tions could be made regarding the SMA patterns. 


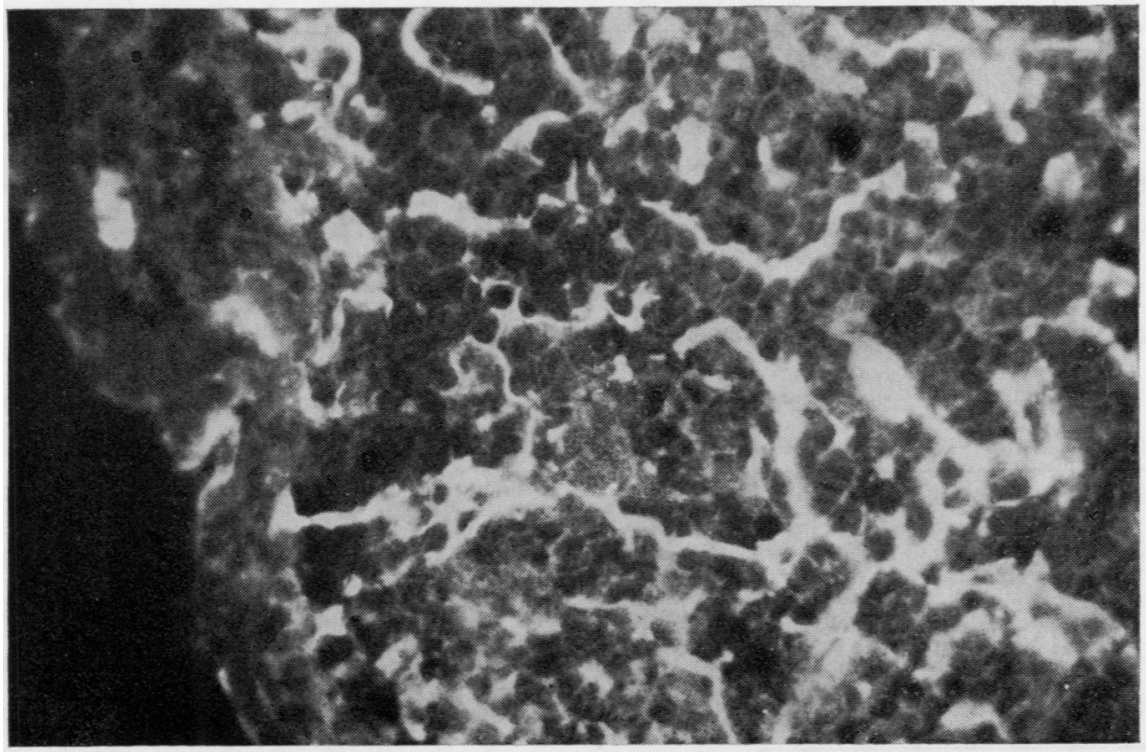

Fig 5 Mouse thymus showing streaks in cortical area.

\begin{tabular}{lllcr}
\hline Thymic IFL & $\begin{array}{l}\text { No. of } \\
\text { Sera }\end{array}$ & \multicolumn{4}{l}{ SMA Pattern } \\
\cline { 3 - 5 } & & $V$ & $G$ & $T$ \\
\hline Medulla only & $18(9)^{2}$ & - & 5 & 13 \\
Cortex and medulla & $29(5)$ & - & 3 & 26 \\
Streaks in cortex & $17(4)$ & - & 4 & 13 \\
No reaction & $35(15)$ & 9 & 20 & 6 \\
\hline
\end{tabular}

Table II Reactions of SMA positive sera with thymus

${ }^{1}$ Titres ranged between 20 and 320 .

${ }^{2}$ Number of patients with chronic active hepatitis in parentheses.

'Streaky pattern was always associated with staining of thymocytes in medulla, or medulla and cortex.

$\mathbf{V}=$ vessels $; \mathbf{G}=$ glomeruli; $\mathbf{T}=$ tubules .

m.

\begin{tabular}{lll}
\hline Mouse Tissue & Anti-sera:SMA & BA- $\theta$ \\
\hline Lymph node & T-areas & T-areas \\
Spleen & T-areas & T-areas \\
Thymus: & Streaks + or - & No streaks \\
Cortex & + or - & ++ \\
Medulla & ++ & + \\
\hline
\end{tabular}

Table III Comparison of human SMA and anti-mouse brain associated- $\theta$

On thymus, sera from patients with chronic active hepatitis stained the medullary lymphocytes more frequently (see table II). Nine of 18 sera which stained medulla exclusively came from this group whereas only five of 29 sera reacting with both medulla and cortex were from $\mathrm{CAH}$ cases. The thymus staining patterns were not related to the CAH subgroups mentioned above. It may also be noted that nearly half the sera which failed to react with thymus came from CAH cases. The finding of cortical streaks could not be correlated with any disease group.

\section{CORRELATION OF SMA TYPES WITH \\ PERIPHERAL CYTOPLASMIC IFL}

For this, a selection was made of 134 high titre sera corresponding unequivocally to the three SMA types (table VI). Weak or equivocal reactions were excluded, for instance, when thyroid peripheral staining was difficult to assess in the presence of

\begin{tabular}{|c|c|c|c|c|c|c|c|}
\hline \multirow[t]{3}{*}{ Disease Category } & \multirow[t]{3}{*}{$\begin{array}{l}\text { Total No. } \\
\text { Patients }\end{array}$} & \multicolumn{6}{|c|}{$\begin{array}{l}\text { Smooth Muscle Antibody Variant } \\
\text { (no. patients) }\end{array}$} \\
\hline & & \multicolumn{2}{|c|}{ SMA-V Titre } & \multicolumn{2}{|c|}{ SMA-G Titre } & \multicolumn{2}{|c|}{ SMA-T Titre } \\
\hline & & Low & High & Low & High & Low & High \\
\hline $\begin{array}{l}\text { Liver diseases } \\
\text { Miscellaneous infection, autoimmune }\end{array}$ & 139 & 31 & 19 & 7 & 34 & 10 & 38 \\
\hline $\begin{array}{l}\text { diseases, and malignancies } \\
\text { Total }\end{array}$ & $\begin{array}{l}173 \\
312\end{array}$ & 83 & 25 & 15 & 12 & 26 & 12 \\
\hline
\end{tabular}

Table IV Distribution of smooth muscle antibody (SMA) variants Low titre $=10-40 ;$ High titre $=80-640$. 


\begin{tabular}{|c|c|c|c|c|}
\hline \multirow[t]{2}{*}{ Type of Liver Disease } & \multirow[t]{2}{*}{ No. Cases } & \multicolumn{3}{|c|}{ Smooth Muscle Antibody Variants } \\
\hline & & $S M A-V$ & $S M A-G$ & $S M A-T$ \\
\hline 'Lupoid hepatitis' ANA 80-640 & 28 & 3 & 14 & 11 \\
\hline Chronic active hepatitis $\mathbf{A N A}=$ neg: $\mathbf{H B}_{\mathbf{s}} \mathbf{A g}=$ neg & 14 & 0 & 7 & 7 \\
\hline Viral hepatitis & 26 & 8 & 4 & 14 \\
\hline Halothane hepatitis & 9 & 5 & 0 & 4 \\
\hline Cirrhosis & 14 & $\mathbf{3}^{1}$ & $9^{2}$ & 2 \\
\hline Total & 91 & 19 & 34 & 38 \\
\hline
\end{tabular}

Table V Distribution of SMA variants in liver diseases: Immunofluorescence titre 1:80-1:640

11 PBC; 23 PBC.

\begin{tabular}{lccc}
\hline & \multicolumn{3}{l}{ SMA Type } \\
\cline { 2 - 4 } & $V$ & $G$ & $T$ \\
\hline Number of cases & & & \\
$\quad$ SMA titre 80-640) & $45(18)^{1}$ & $41(28)$ & $48(33)$ \\
Hepatocytes & $5(3)$ & $1(0)$ & $18(15)$ \\
Thyroid epithelium & $4(2)$ & 0 & $3(3)$ \\
Liver and thyroid & 0 & 0 & $11(8)$ \\
Total & 9 & 1 & 32 \\
\hline
\end{tabular}

Table VI Pericellular IFL in liver and thyrotoxic thyroid in relation to SMA types

${ }^{1}(\quad)=$ liver disease.

microsomal or mitochondrial antibodies. Peripheral IFL in hepatocytes in the absence of thyroid staining was found in 24 cases, 18 of which were SMA-T, one SMA-G, and 5 SMA-V. There were at least three different appearances:

1 smooth polygonal; 2 polygonal with brighter dots corresponding to tight junctions; 3 double line interrupted staining (bile canalicular).

Thyroid peripheral IFL with negative hepatocyte staining was seen in seven instances, three SMA-T and four SMA-V. Here again, the appearances were not totally uniform, some sera showing a thick line and others a very slender one at the periphery of the thyroid epithelial cells. Both liver and thyroid showed peripheral IFL with 11 sera, all corresponding to SMA-T. The presence or absence of peripheral IFL in these two organs did not correlate with the SMA titre. In some sera, titration on kidney, thyroid, and liver reached the same endpoint, while in others the peripheral IFL in the latter two organs disappeared more quickly. As seen in table VI, these correlations were not specifically related to liver diseases.

\section{ABSORPTION STUDIES}

Forty-three sera with SMA reactivity in titres between 40 and 640 were absorbed with purified actin. Twenty-four were SMA-T, 18 SMA-G, and one SMA-V. Only two sera could not be absorbee with actin - the SMA-V serum and an unusual SMAN $T$ serum which also stained intercalated discs itr heart muscle and was derived from a child with retroperitoneal tumour. Forty-one sera lost all theif IFL, including the staining on liver and thyroid?

\section{Discussion}

The present attempt to classify smooth muscle anti $\vec{\oplus}$ bodies occurring in human sera was morphos logical. It has been obvious for some years that 8 number of IFL patterns were observed on differen tissues. At first it was considered that individual ser contained a mixture of antibodies to related tissug antigens but when monoclonal proteins with SM reactivity showed different IFL patterns it en $\overrightarrow{\bar{F}}$ couraged the idea that these could be due to $\underset{\$}{\$}$ single SMA-related antigen distributed in many cet types. Gabbiani et al (1973) were the first to suggesw. that sera from chronic active hepatitis cases con tained anti-actin antibodies, and this was confirme by Fagraeus and her co-workers and now also by our results. Actin of almost identical composition is widely distributed in animal tissues (Pollard an® Weihing, 1974), especially in smooth and striated muscle, and in intracellular contractile fibril (Lazarides and Weber, 1974; Fagraeus et al, 1975 Norberg et al, 1975) of liver, thyroid, and kidney including the glomerulus. Trenchev et al (19748 raised anti-actin antibodies in rabbits and obtaine glomerular staining and a pattern on other organs resembling SMA-T.

Strong human anti-actin antibodies stain kidne? with the SMA-T pattern and also show a pericellulas IFL on liver and thyroid but some weak sera may give the SMA-V appearance yet be absorbed by actin. Nevertheless there are high-titre sera of SMA-Gं pattern that were completely absorbed with actir suggesting that some patients may make antibodies to different antigenic sites on the actin molecule? some of which may not be exposed in intracellulas fibrils. The inability to stain skeletal muscle I bands 
by weaker sera is further evidence that the actin antigenic sites may be inaccessible owing to the surrounding myosin filaments, depending on the degree of contraction during fixation. Some hightitre SMA sera cannot be absorbed by actin and we have evidence that there are at least three other antigens involved. The high-titre SMA-V sera are against antigens peculiar to smooth muscle and one of these is probably an anti-smooth muscle myosin (Fairfax et al, unpublished), while others may be against proteins surrounding the contractile fibrils. The SMA-T serum which could not be absorbed by actin showed a very unusual pattern. The antigen has not yet been identified and appears related to cell junctions in smooth and cardiac muscle, and in Purkinje fibres.

The thymus results corresponded, to a certain degree, with those reported by Fagraeus et al (1973). Three of our anti-actin sera showed staining of the cortex and medulla but no 'streaks', while one serum which could not be absorbed showed streaks, suggesting that this pattern corresponds to a different antigen.

In view of the high SMA titres seen in some cases of CAH an attempt was made to correlate subgroups of this syndrome with the SMA patterns (table V). In 'lupoid' hepatitis ANA is the chief marker and about half the cases also showed SMA which could be SMA-T or SMA-G and more rarely SMA-V. In addition, there is a small group of patients showing persistent SMA in the absence of ANA, who could represent a different disease (Dawkins and Joske, 1973). It is as yet unexplained why antibodies to actin should be a particular feature of the autoimmune forms of $\mathrm{CAH}$, while antibodies to other smooth muscle proteins were found mostly in patients with disorders not involving the liver.

We should like to acknowledge our constant collaboration with Dr Roger Williams and his team (Kings College Hospital Liver Unit), and to thank all the physicians who sent sera from their patients.

M. Swana, P. Collins, and S. Bedi gave their expert technical assistance and Miss H. Fischler helped with the manuscript.

GFB is in receipt of a British Council Scholarship, $\mathrm{AF}-\mathrm{C}$ is a Wellcome Fellow, and AJF received research grants from St. George's Hospital and the Wellcome Foundation. Work in the Department of Immunology is also supported by grants from the World Health Organization and the Medical Research Council.

\section{References}

Adelstein, R. S., Godfrey, J. E., and Kielley, W. W. (1963).
G-actin: preparation by gel filtration and evidence for a double stranded structure. Biochem. biophys. Res. Commun., 12, 34-38.

Ajdukiewicz, A. B., Dudley, F. J., Fox, R. A., Sherlock, S., and Doniach, D. (1972). Immunological studies in an epidemic of infective, short incubation hepatitis. Lancet, 1 , 803-806.

Andersen, P. (1974). Indirect immunofluorescence studies of smooth muscle antibodies. Acta path. microbiol. scand., B, 82, 577-584.

Becker, C. G. (1972). Demonstration of actomyosin in mesangial cells of the renal glomerulus. Amer. J. Path., 66, 97-110.

Becker, C. G. and Nachman, R. L. (1973). Contractile proteins of endothelial cells, platelets and smooth muscle. Amer. J. Path., 71, 1-22.

Behnke, O. (1974). Microtubules and microfilaments. Triangle, 13, 7-16.

Biberfeld, G., Fagraeus, A., and Lenkei, R. (1974). Reaction of human smooth muscle antibody with thyroid cells. Clin. exp. Immunol., 18, 371-377.

Dawkins, R. L. and Joske, R. A. (1973). Immunoglobulin deposition in liver of patients with active chronic hepatitis and antibody against smooth muscle. Brit. med. J., 2, 643645.

Doniach, D. and Bottazzo, G. F. (1976). Chronic active hepatitis viewed as a syndrome. Folia allerg. (Roma). (In press).

Doniach, D., Roitt, I. M., Walker, J. G., and Sherlock, S. (1966). Tissue antibodies in primary biliary cirrhosis, active chronic (lupoid) hepatitis, cryptogenic cirrhosis and other liver diseases and their clinical implications. Clin. exp. Immunol., 1, 237-262.

Fagraeus, A., Lidman, K., and Norberg, R. (1975). Indirect immunofluorescence staining of contractile proteins in smeared cells by smooth muscle antibodies. Clin. exp. Immunol., 20, 469-477.

Fagraeus, A., The, H., and Biberfeld, G. (1973). Reaction of human smooth muscle antibody with thymus medullary cells. Nature New Biol., 246, 113-115.

Fairfax, A. J. and Doniach, D. (1976). Autoantibodies to cardiac conducting tissue and their characterization by IFL. Clin. exp. Immunol., 23, 1-8.

Fairfax, A., Doniach, D., and Wells, C. E. C. (1976). A membrane associated autoantibody in a case of myasthenia gravis with chronic hepatitis. Clin exp. Immunol., (In press).

Farrow, L. J., Holborow, E. J., and Brighton, W. D. (1971). Reaction of human smooth muscle antibody with liver cells. Nature New Biol., 232, 186-187.

Farrow, L. J., Holborow, E. J., Johnson, G. D., Lamb, S. G., Stewart, J. S., Taylor, P. E., and Zuckerman, A. J. (1970). Autoantibodies and the hepatitis-associated antigen in acute infective hepatitis. Brit. med. J., 2, 693-695.

Gabbiani, G., Ryan, G. B., Lamelin, J. P., Vassalli, P., Majno, G., Bouvier, C. A., Cruchaud, A., and Lüscher, E. F. (1973). Human smooth muscle autoantibody. Amer. J. Path., 72, 473-484.

Galbraith, R. M., Smith, M., Mackenzie, R. M., Tee, D. E., Doniach, D., and Williams, R. (1974). High prevalence of seroimmunologic abnormalities in relatives of patients with active chronic hepatitis or primary biliary cirrhosis. New Engl. J. Med., 290, 63-69.

Gyöngyössy, M. I. C. and Playfair, J. H. L. (1973). Indirect immunofluorescence of mouse thymus-derived cells using heterologous anti-brain serum. Cell Immunol., 7, 118-123.

Holborow, E. J. (1972). Smooth muscle antibodies and antigens. Proc. roy. Soc. Med., 65, 481-482.

Holborow, E. J., Hemsted, E. H., and Mead, S. V. (1973). Smooth muscle antibodies in infectious mononucleosis. Brit. med. J., 3, 323-325. 
Huriaux, F., Hamoir, G., and Oppenheimer, H. (1967). Low molecular weight fragment from succinylated myosin of bovine carotids. Arch. Biochem., 120, 274-284.

Johnson, G. D., Holborow, E. J., and Glynn, L. E. (1965). Antibody to smooth muscle in patients with liver disease. Lancet, 2, 878-879.

Johnson, G. D., Holborow, E. J., and Glynn, L. E. (1966). Antibody to liver in lupoid hepatitis. Lancet, 2, 416-418.

Lazarides, E. and Weber, K. (1974). Actin antibody: the specific visualization of actin filaments in non-muscle cells. Proc. nat. Acad. Sci. (Wash.), 71, 2268-2272.

Lidman, K., Eriksson, U., Fagraeus, A., and Norberg, R. (1974). Antibodies against thyroid cells in yersinia enterocolitica infection. Lancet, 2, 1449.

McMillan, S. A. and Haire, M. (1975). Smooth muscle antibody in patients with warts. Clin. exp. Immunol., 21, 339 344 .

Norberg, R., Fagraeus, A., and Lidman, K. (1975). Reaction of human smooth muscle antibody with human platelets. Clin. exp. Immunol., 21, 284-288.

Pollard, T. D. and Weihing, R. R. (1974). Actin and myosin in cell movement Crit. Rev. Biochem., 2, 1.

Roux, M. E. B., Florin-Christensen, A., Arana, R. M., and Doniach, D. (1974). Paraproteins with antibody activity in acute viral hepatitis and chronic autoimmune liver diseases. Gut, 15, 396-400.

Sutton, R. N. P., Emond, R. T. D., Thomas, D. B., and
Doniach, D. (1974). The occurrence of autoantibodies ir infectious mononucleosis. Clin. exp. Immunol., 17, 427-436ठํㅡㄹ

Trenchev, P., Sneyd, P., and Holborow, E. J. (1974). Immu: nofluorescent tracing of smooth muscle contractile proteir antigens in tissues other than smooth muscle. Clin. exp:+ Immunol., 16, 125-135.

Wager, O., Räsänen, J. A., Haltia, K., and Wasastjerna, C드

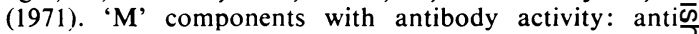
smooth muscle, anti-thyroglobulin and anti-streptolysin-CD activity in five M component sera. Ann. clin. Res., 3, 86-97?

Walker, J. G., Doniach, D., Willette, M., Cameron, S., anผึ Dane, D. S. (1970). Virus antigen, immunoglobulins and autoantibodies in acute hepatitis. (Abstr.), Gut, 11, 369.

Wasserman, J., Glas, U., and Blomgren, H. (1975). Anti $\overrightarrow{\vec{H}}$ bodies in patients with carcinoma of the breast: correla tion with prognosis. Clin. exp. Immunol., 19, 417-422.

Whitehouse, J. M. A. and Holborow, E. J. (1971). Smootફ muscle antibody in malignant disease. Brit. med.J., 4, 511 No 513.

Whittingham, S., Irwin, J., Mackay, I. R., and Smalley, $M_{A}^{*}$ (1966a). Smooth muscle autoantibody in 'autoimmune hepatitis. Gastroenterology, 51, 499-505.

Whittingham, S., Mackay, I. R., and Irwin, J. (1966b). Auto을 immune hepatitis. Immunofluorescence reaction with cytoplasm of smooth muscle and renal glomerular cells Lancet, 1, 1333-1335. 